\title{
Pictures on a Page: Towards a History of the Photobook in New Zealand
}

Athol McCredie

Keywords: \#photobook \#New Zealand \#photography book \#photography album \#beautiful New Zealand book \#picture book

The term 'photobook' is very recent, yet numerous studies now survey histories of its development right back to the invention of photography. This article examines photographic books in New Zealand up to 1970 and concurrently explores definitions of the 'photobook' and whether, or to what extent, they can be applied to any of these publications. It considers nineteenth century albums, early scientific publications, and in particular, the books of scenery that have become such a stock item of New Zealand photographic book production. It also looks at a handful of books in the 1950s and 1960s that reacted against the scenic, as well as books of the 1960s inspired by photojournalism. 
The term 'photobook' is commonplace in photographic art discourse today yet is absent from standard dictionaries. As an easy contraction of 'photography book' it is difficult to pinpoint when it was originally coined and by whom, but its first use in a title is Children of the World: A Photobook by Sam Waagenaar in 1959.' However, the expression did not seem to catch on; few other books incorporated it in their titles over the next four decades and it appears nowhere in the text of the first international survey of photographic books, The Book of 101 Books: Seminal Photographic Books of the Twentieth Century, edited by Andrew Roth in 2001.

Common use of the term photobook dates from the 2000s, and was undoubtedly popularised by Gerry Badger and Martin Parr's three volume The Photobook: A History, the first instalment of which was published in 2004. This was a period when small run, often self-published photography books began to appear in significant numbers. These were a photographic form of the artist's book. Badger and Parr seem to have borrowed the term in this sense and applied it retrospectively to a history of photography books, following photography writer and curator David Campany's observation that the "nifty little invention" of the compound noun photobook turns "an infinite field (books with photographs in them) into something much more definable". ${ }^{2}$

Badger and Parr have effectively devised a new history of photography via the photobook that "embraces the aesthetic and the technical, the art and the mass medium, [one that] has hardly been considered by historians". ${ }^{3}$ It clearly leaves out many types of photography, such as the snapshot, commercial portraiture, advertising and news photography, but it also highlights an overlooked way in which photographs have been disseminated and how we often experience them. It further foregrounds an issue that has received little critical attention: rather than how photographs work as single images, how they operate together. As David Campany observes:

For over a century nearly all photographic culture - from mainstream magazine photo-essays to independent books and website presentations - has involved the ordering of bodies of images. 'Composition' is not confined to the rectangle of the viewfinder; it is also a matter of the composition of the set, series, suite, typology, archive, album, sequence, slideshow, story and so forth. ${ }^{4}$

It seems, then, that it would be useful to begin thinking about a history of photography books in New Zealand, and seeing how many might belong to that narrower field termed the photobook - a form whose definition I will explore by way of examples as we go.

To begin, what is a book? The New Zealand Oxford Dictionary defines it as "a written or printed work consisting of pages glued or sewn together along one side and bound in covers". In turn, a photobook, for Wikipedia, is "a book in which photographs make a significant contribution to the overall content ${ }^{\prime} .{ }^{5}$ Badger and Parr's opening definition is of a book where the "primary message is conveyed by photographs". ${ }^{6}$ Neither this nor Wikipedia' explanation takes us much beyond an intuitive notion of a photography book, let alone its subset, the photobook. However, Di Bello and Zamir more usefully add that in the photobook the photographs "are integral and essential, and not merely supplemental" in producing the book's overall meaning. ${ }^{7}$

The first potential photobook candidates in New Zealand are nineteenth-century photographic albums. These could be family albums of studio portraits, precursors to the snapshot album; or the albums of scenic views, forerunner of printed books of scenery. Reproduction on the printed page wasn't technically possibly in any practicable way until the late 1880 s at best, so photographs were in the form of original photographic prints in these earliest instances of photographic books.

Such albums are by definition photographic, and materially they are books, but they don't quite match our notion of a book's conceptual nature. They are termed albums for a reason: they are collections, compilations, where one photograph is commonly added after another according to when it was taken or acquired by the compiler. In this respect they lack a coherent logic, an organised form, qualities we expect of a book. They typically trail off towards the end, where the compiler lacked sufficient photographs to match the number of pages, or simply lost interest in continuing.

The albums rarely have a visual narrative - a criterion used for contemporary photobooks in the 2017 New Zealand Photobook of the Year Awards. ${ }^{8}$ There may be narratives within the albums, but these tend to be ones personally conveyed by compilers to friends or relatives in intimate settings: "this is Aunty Violet and she was married to Uncle Jim"; "that is where we stayed on our honeymoon".

The visual narrative requirement is quite a restrictive one, however. What about photobooks that operate poetically, where the individual images still compound but without a linear story? In a taxonomy of the photobook Jörg M Colberg identifies the 'poetic' and 'elliptical' photobook, under a heading of the 'lyrical' form. ' Badger 
and Parr also suggest that a photobook is a type of photography book that has a "particular subject - a specific theme". ${ }^{10}$ The photobook, they assert, "should be an extended essay in photographs", and...follow its theme with "intention, logic, continuity, climax, sense and perfection, as Lincoln Kirstein put it". ${ }^{11}$ This is primarily achieved by making the images work together, with "each image placed so as to resonate with its fellows as the pages are turned". The result makes "the collective meaning more important than the images' individual meanings...the sum, by definition, is greater than the parts".12

The early albums might have a specific subject (portraits or scenic views usually), but rarely were their images marshalled together into a larger theme. Another limitation is that they were generally not published. Badger and Parr are ambivalent on whether publication - making a book available to the public for a price - is a necessary criterion for a photobook. They include Anna Atkins' Photographs of British Algae (1843-53) in their selection of featured photobooks but note that Fox Talbot's The Pencil of Nature (1844-46) would be considered by many as the first photobook because it was produced and sold in some numbers, whereas Atkins distributed her slightly earlier Photographs of British Algae to only a few friends. We intuitively think of a book as something published, but the dictionary definition noted above does not require this at all. ${ }^{13}$

Nevertheless, some hand-compiled albums of pre-selected albumen print images were produced and sold by New Zealand photographic firms. These had no empty pages, and tended to focus on the scenic wonders of New Zealand. An example is New Zealand: Land of Loveliness produced by the Dunedin studio of the Burton Brothers in the $1880 \mathrm{~s} .{ }^{14}$ It was much smaller and lighter than regular nineteenthcentury albums and came in a number of subject matter variations. It was explicitly marketed for sending overseas to the "dear old folks at home" as a "Christmas present [of] Views of the Land we live in"15 but could equally have served as a readily portable souvenir of New Zealand for tourists.

One of the most impressive studio-compiled albums is James Bragge's Wellington to the Wairarapa of the mid-1870s. ${ }^{16}$ It consists of a series of 40 to 45 (there are slight variations from copy to copy) albumen prints made from $10 \times 12$ inch negatives. The photographs are shots taken along the road from Wellington and over the Remutaka Range into the Wairarapa, so this album does have a definite narrative sequence. It is not clear how many albums Bragge produced but at least six survive today.

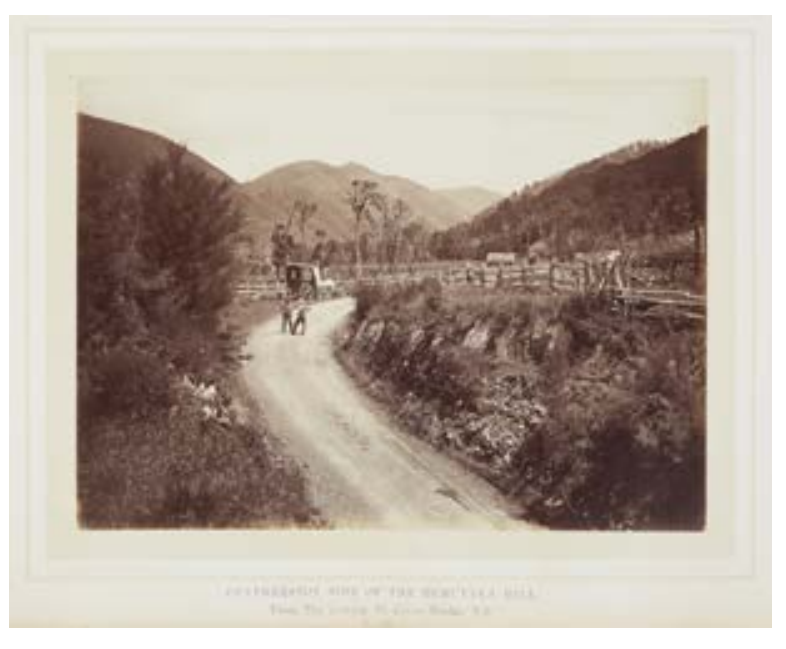

Vying with Bragge's album for status as New Zealand's first photobook, insofar as it is on a single subject and conceived as an integrated whole, is Daniel Mundy's 1875 Rotomahana and the Boiling Springs of New Zealand: A Photographic Series of Sixteen Views. It takes the form of a conventional book, with a lavish, gold embossed cover and images of the Pink and White Terraces and other thermal features around Lake Rotomahana. Each photograph is on its own leaf, and these are interspersed with printed texts by the eminent GermanAustrian geologist Ferdinand von Hochstetter, who had visited the area in 1859. The book was published in London, which was not unusual for New Zealand books for many decades, and produced in a run of 250 copies. The beautifully toned photographs, perfectly preserved today, are credited in the book as reproduced by the autotype process. This was apparently a proprietary form of carbon printing and suggests that the photographs were individually hand printed.

Another focussed topic book of this time, and definitely hand produced, was Herbert Dobbie's cyanotype (blueprint) book New Zealand Ferns: 148 Varieties (1880). It was produced in several versions and in editions of perhaps up to 50 copies each. It consisted of photograms of ferns, made by exposing fern specimens against sensitised photographic paper to produce white silhouettes, just as Anna Atkins had done 37 years earlier. This was a cheap and easy way to produce a fern identification guide, although a reviewer of the time suggested they were not entirely satisfactory for this purpose and might better serve as a 'handsome ornament for the drawing room'. ${ }^{17}$ 


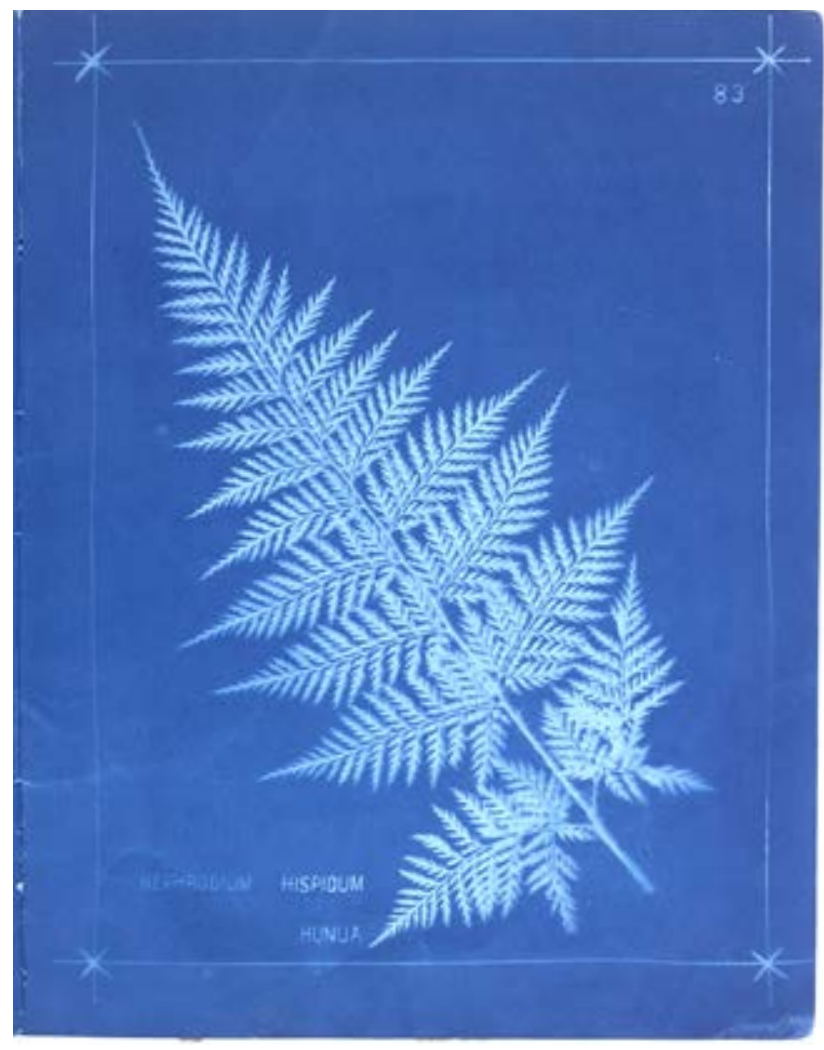

Herbert Dobbie, Nephrodium hispidum Hunua, from the photographic book, ns: 148 Varieties, 1880, p. 83, Te Papa, 0.039653
Dobbie made no apparent attempt to structure his books, for the ferns are sequenced randomly without regard to genus and locality. Some might consider that the images are not photographs because they were made by direct contact printing of ferns upon photographic paper, without the use of a camera at all, thereby disqualifying the work as a photobook on this ground alone, but this seems a fine point.

The development of photomechanical printing from the 1880 s enabled scholarly publications to be photographically illustrated. Most lavish amongst them was Augustus Hamilton's The Art Workmanship of the Maori Race in New Zealand (often known simply as Maori Art) published between 1896 and 1901 in five parts. When bound as a single volume, the total of 278 set a record for the number of photographs reproduced in a New Zealand book that probably lasted at least a century. However, it is difficult to see it as a photobook, for it works primarily as a catalogue - of the varieties of taonga Māori - and in this sense its images are simply illustrative. They visually describe objects, but it is the objects that are of concern, not the qualities of the photographs; nor is the whole greater than the sum of its parts.

Much the same could be said for another substantially illustrated scientific book of the period, the two-volume The Rocks of the Cape Colville Peninsula, Auckland, New Zealand of 1905-1906 by WJ Sollas and the government geologist Alexander McKay. This includes 32 landscape views and 177 full-page photographs of thin sections (photomicrographs), all taken by McKay.

Photomechanical half-tone printing saw the nineteenth century scenic album gradually supplanted by booklets, postcards and illustrated magazines. The 30-page booklet Album of New Zealand Scenery: The Maori at Home and the Thermal Springs of the North Island published by Muir \& Moodie in 1903 is a case in point. It uses photographs mostly taken by the Burton Brothers studio two decades earlier and is essentially a scenic album of the sort they once compiled, but now turned into print and reduced drastically in size. More substantial scenic books were not produced until the 1920s, perhaps because the lavish Christmas issues of magazines with picturesque imagery such as the New Zealand Graphic, Auckland Weekly News and Otago Witness, as well as Brett's Christmas Annual, filled a similar market in the early twentieth century.

Tourists were always a market for scenic publications and the Department of Tourist and Health Resorts, set up by government in 1901 to better co-ordinate the growing tourism industry, was active in the field from at least 1917. Its productions were still thin enough to be considered booklets, but grew in format to the $240 \times 210$ $\mathrm{mm}$ New Zealand: Paradise of the Pacific (1928) and the larger $295 \mathrm{x}$ $230 \mathrm{~mm}$ (approximately A4) New Zealand: Scenic Playground of the Pacific (1933 and 1936).

Other publishers produced more lavish versions. They include Pictorial New Zealand: Photographic Studies, published by Whitcombe and Tombs in the 1940s and New Zealand Railways Illustrated $(1937,1938)$. The former was perhaps not specifically designed to stimulate tourism - though it includes numerous images of tourists and tourism sites - but more as a commercial picture book proposition in its own right. It is well designed and illustrated 'with the best examples of the photographer's art'.18 These included work by many of the notable names of the period, including George Chance, Thelma Kent, Ellis Dudgeon, Leonard Casbolt and William Hall Raine. The images are excellently reproduced in soft, warm-toned letterpress, suitably matching their pictorialist tendency. 


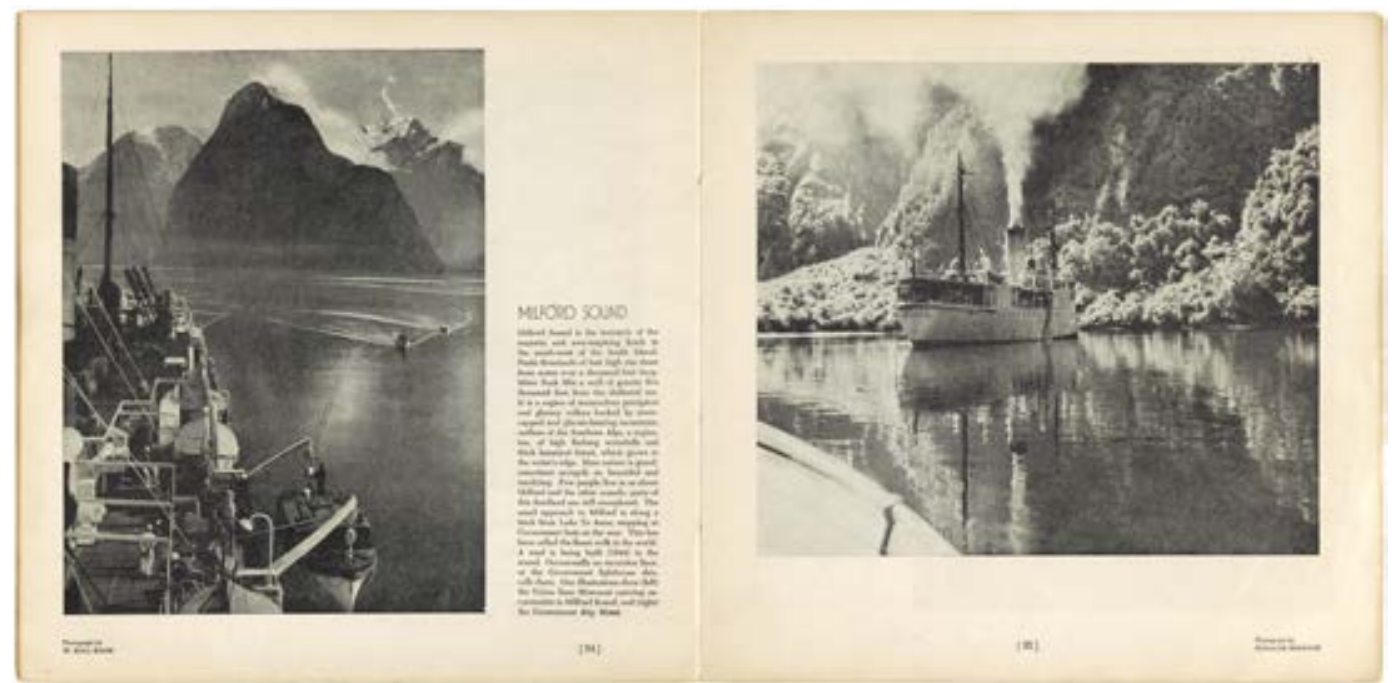

Pictorial New Zealand: Photographic Studies, c. 1944, pp.54-55. Collection of the author.

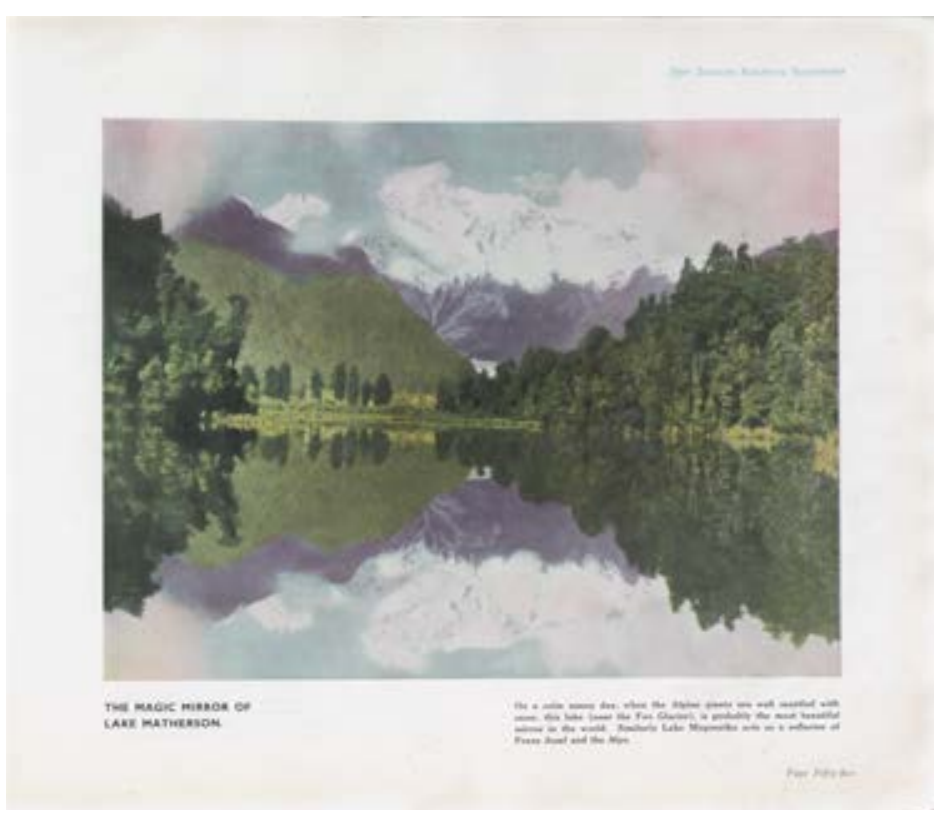

Rather a contrast in production values is New Zealand Railways Illustrated. Published by the New Zealand Railways Department to promote rail tourism, this thicker publication consists of 80 handcoloured scenic images, many featuring trains. The colouring is crude and lurid, but has a charm of its own in today's eyes.

These, and a few other books, established what can be termed the 'beautiful New Zealand' genre of photography book..$^{19}$ This developed to another level in the 1960s and has become a stock item for publishers ever since. The two significant publications in the 1960s were Kenneth and Jean Bigwood's New Zealand of 1963 and Brian Brake and Maurice Shadbolt's New Zealand: Gift of the Sea of the same year. The Bigwood's effort was a substantial volume with an essay by Monte Holcroft and tipped-in calendar-style colour images. Although the production quality was considerably higher than any earlier scenic publication, there was no conceptual advance on the early album approach of one unrelated image after another. Such was definitely not the case with Gift of the Sea, however. Brake applied the experience he had gained overseas as a photojournalist and illustrative photographer, as well as an understanding of editing from his time as a film maker with the National Film Unit. He paid a great deal of attention to sequence and juxtaposition and his layout leaves no page spread looking the same as another, with images sometimes full spread, other times sliced and butted across the page, and every option in between. It is undoubtedly the most sophisticated photography book published in New Zealand to this point and certainly allows us to call it a photobook for the way it 'works' images, treating them as components of a larger entity, like sentences or paragraphs in a book.

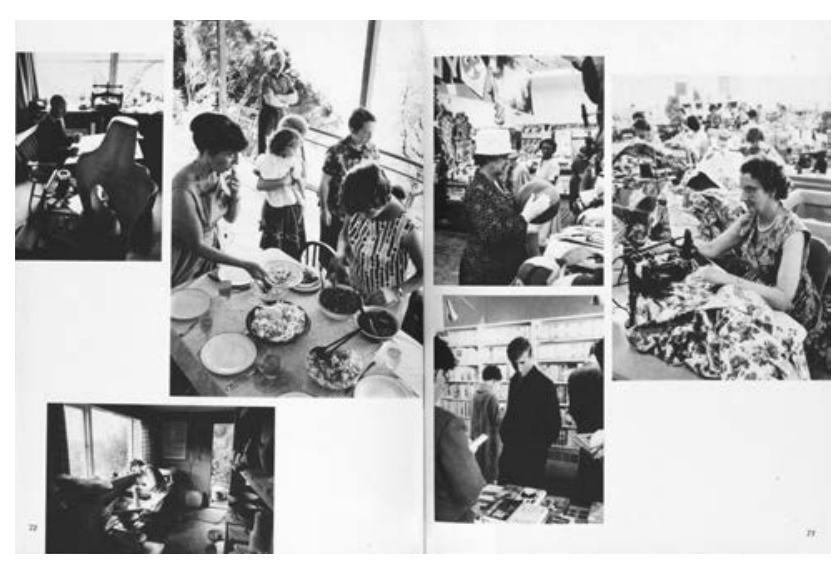

Brian Brake and Maurice Shadbolt, New Zealand: Gift of the Sea, 1963, pp. 72-73. Te Papa Collection. 


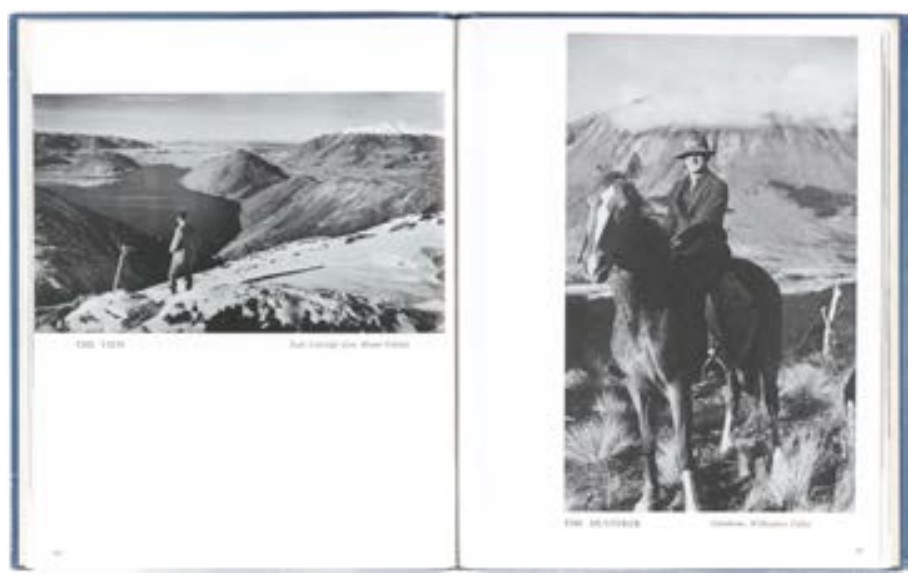

John Pascoe, The Mountains, the Bush and the Sea: $A$ pp.30-31. Te Papa Collection.
New Zealand and Gift of the Sea sold well through the 1960s. Clearly there was now a market beyond tourists for picture books on New Zealand. Perhaps this had to do with an emerging nationalism in the wake of WWII, as ties with Britain were gradually severed. Perhaps it was because the increasing use of colour printing made photographic books more attractive. The Bigwoods capitalised on the new trend with six titles alone: New Zealand in Colour (vols 1, 1961; vol 2, 1962), The New Zealand Maori in Colour (1963), New Zealand's South Island in Colour (1966), The New Zealanders in Colour (1965) and New Zealand Farming in Colour (1967) - all, it has to be said, staid and unimaginative efforts. In the 1970s and 1980s other players entered the market and books by Eric Taylor, James Siers, Martin Barriball, Warren Jacobs, Robin Smith, Phillip Temple, and Robin Morrison all demanded a section of their own in bookstores.

There was also a counter trend to the scenic, touristic view of New Zealand landscape, beginning with John Pascoe's The Mountains, the Bush and the Sea: A Photographic Report in 1950. Pascoe wrote in his introduction: "My first aim in this photographic report is to relate mountain, forest and coastline environment to the lives of people".

For Pascoe the cities were occupied by "stuffed shirts". The real New Zealanders were found exploring or living in the backcountry, and in this book he placed them in or against images of this environment. Though rather unsophisticated both in its images and design, this was one of the first books in New Zealand where the photographs worked together to develop an argument and convey a personal vision. It was also the

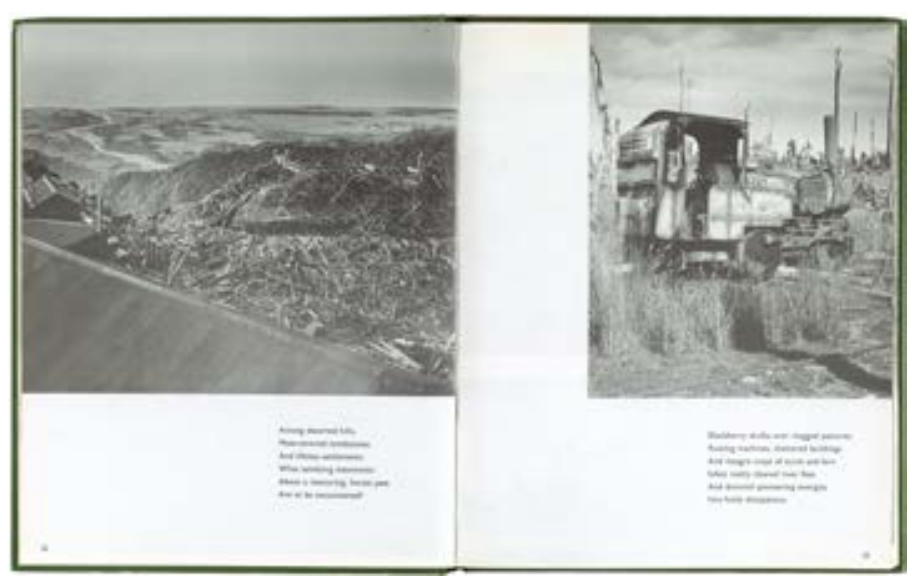

Les Cleveland, The Silent Land, 1966, pp. 22-23. Te Papa Collection. first to begin to meet a criterion formulated by photographer John Gossage for great photobooks: that the photographs should "function as a concise world within the book itself".20

A handful of other books of the 1950s and 60 s also turned their back on tourist imagery to make more personal observations with black and white photographs. Each, coincidentally, focussed on the West Coast of the South Island. In Westland's Wealth (1959) photographer John Johns and writer CGR Chavasse argued against the squandering of the forest resource through poor management practices. VC Browne's The Coast used mainly aerial photographs to find a stark beauty in coastlines, rugged mountains, winding rivers and street grids of small towns. Whites Aviation had published a book of aerial views across the whole of New Zealand in 1952 (Whites Pictorial Reference of New Zealand) but The Coast was a more aesthetically based collection compared with the catalogue-like nature of the Whites publication.

Most personal of all was Les Cleveland's The Silent Land of 1966. This book concentrated on the landscape and people of Westland and the echoes of failed nineteenth-century dreams of progress Cleveland found in decaying buildings and abandoned ventures. Accompanying the photographs is a long prose poem by Cleveland that helps structure the photographs into a narrative and bring out their intended meaning. As noted by Di Bello and Zamir, as well as Campany, ${ }^{21}$ the interaction of text and photographs is not covered in Badger and Parr's definition of a photobook as one in which the primary message is conveyed by photographs. But many well-known photobooks are exactly works 
where word and image mutually support each other, with neither subservient to the other - including Land of the Free (1938) by Archibald MacLeish, that was a model for Cleveland. The Silent Land was not the only book in the 1960s that integrated text and photographs. A group of small 'how others live' books for and about children all appeared at the beginning of the decade. These took their lead from the photojournalism of major international picture magazines like Life and Picture Post that featured photo essays supported with text. Each contained a story told by photographs and words together, and would have been intended as 'readers', books where the pictures could help guide children through text. In this respect the extent to which either images or texts carry the story depends on the age of the reader. As adults we might even entirely dispense with the text.

Hey Boy! (1962) was the first of these books, and it followed the daily life of a Hawaiian-Māori boy and his family in urban Auckland, with photographs by Bernie Hill and text by his wife Anne. In 1964 a quartet of further books or booklets appeared. Ans Westra's Washday at the Pa is the best known, largely for the controversy that surrounded its publication by the Department of Education where complaints that the images represented Māori as stereotypically living in poverty caused it to be withdrawn from circulation in schools and copies destroyed. Washday was conceived by Westra on the spot while she spent a day photographing a Māor family in rural Ruatōia, and she later wrote a text to hold the photographs together. National Publicity Studios photographe Gregory Reithmaier followed a similar conceptual format but with a rather more stilted result when he covered a day in the life of a Māori teenager in Rotorua with Rebecca and the Maoris. Gay and Georg Kohlap traced the farm life of a boy in David: Boy of the High Country and Westra followed a Tongan boy in another Department of Education booklet, Viliami of the Friendly Islands. Each of these books drew on the photo essay form, with images laid out in deliberate sequences that paid attention to the spaces between them and how each spoke to the other to create a narrative whole.

Westra continued with further photo and text booklets for schools and families in the 1960s, though in each case others wrote the text. She also published her magnum opus,
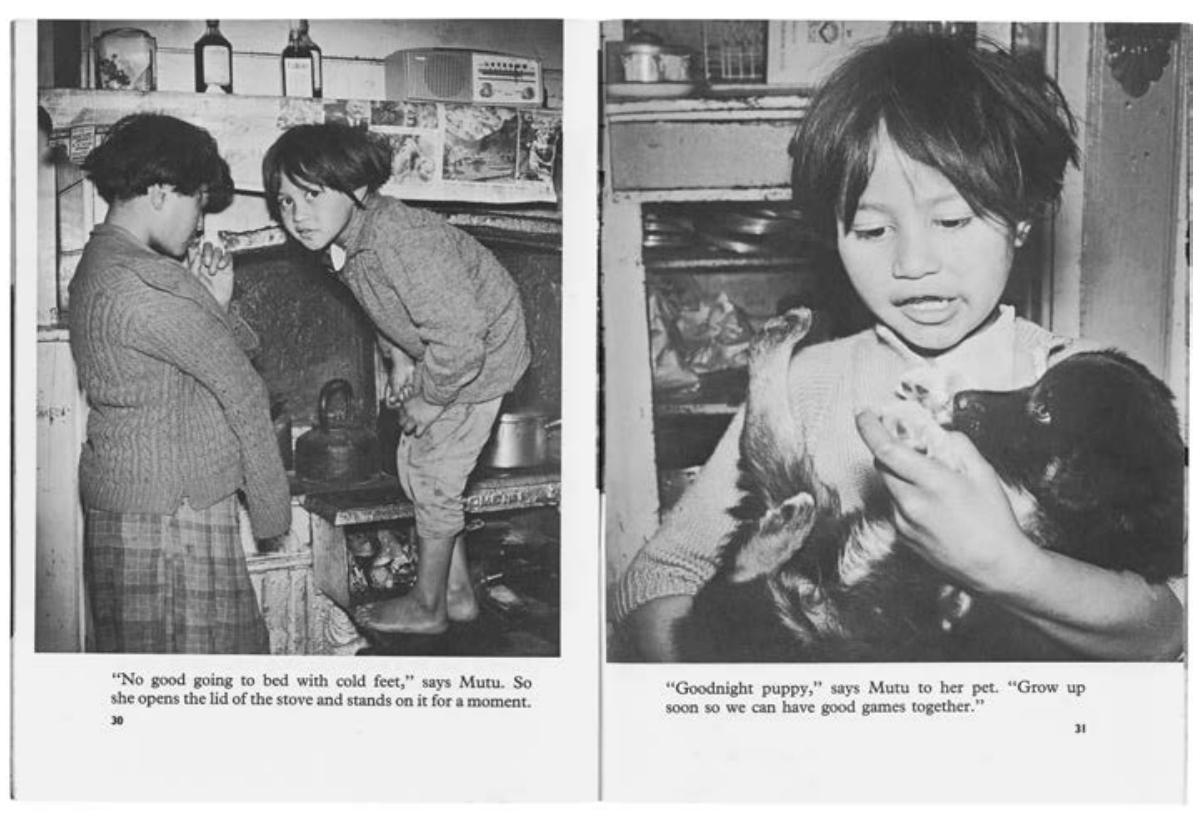

Ans Westra, Washday at the Pa, 1964, pp. 30-31. Te Papa Collection.
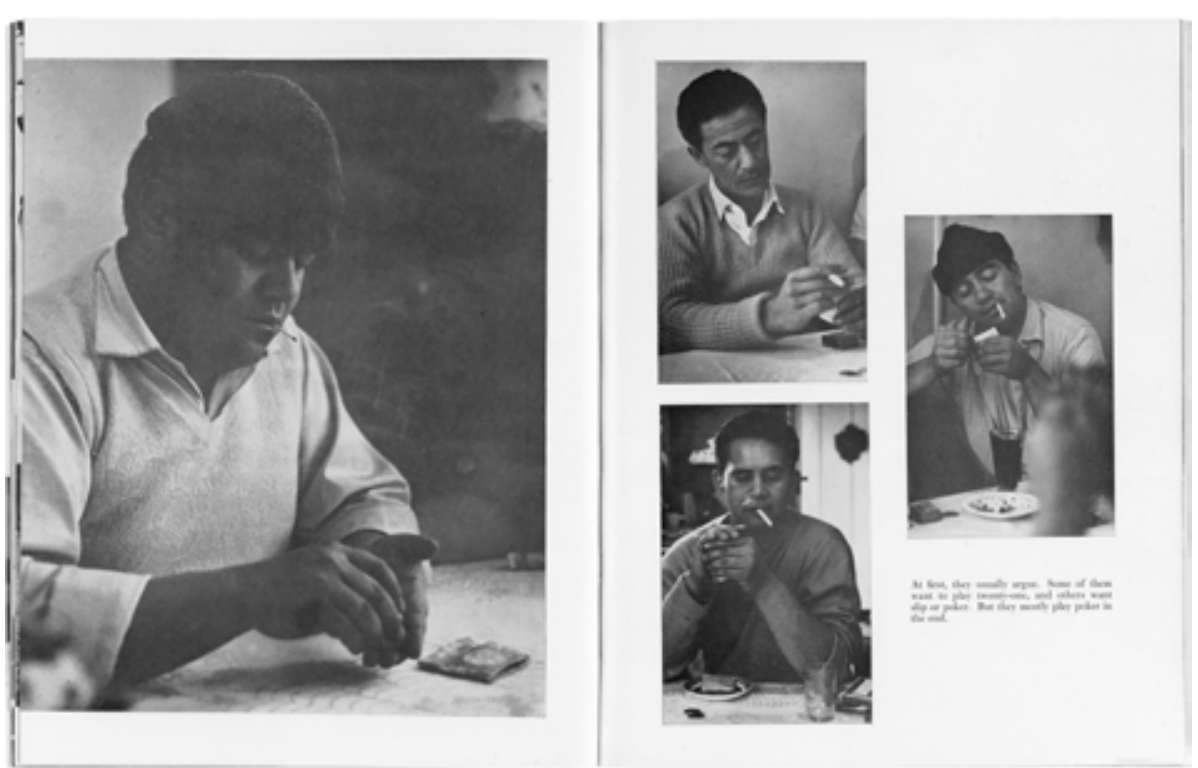

Bernie Hill and Anne Hill, Hey Boy!, 1961 [unpaginated, pp. 53-54]. Te Papa Collection. 
Maori, in 1967. Here the text - a series of essays by James Ritchie and short pieces by Māori writers - operated independently of the photographs, complementing them, as had been the case with Maurice Shadbolt's text for Gift of the Sea. Also like Gift of the Sea, the book was finely printed in gravure and skillfully, if rather more soberly, designed. It was broadly structured on a theme of the cycle of life and death (inspired by the 1955 Museum of Modern Art Family of Man exhibition and catalogue) but otherwise without an explicit narrative.

1967 was also the year Gary Baigent's The Unseen City: One Hundred and Twenty-Three Photographs of Auckland was published. Like Pascoe, Cleveland, Johns and Browne's books it was not intended to present a view of its subject that would appeal to the tourist. It depicted an image of Auckland which civic boosters would have found displeasing: run-down student flats, backyard parties, late night street life, boozy public bars, and waterside labouring. The rough life styles it depicted were matched by the rough photography (intentionally, with a shot-from-the-hip look to many images) and rough printing (not so intentional). In its downbeat subject matter, subjective approach and stream of consciousness nature, The Unseen City looks like it was inspired by Robert Frank's 1959 The Americans, but Baigent did not see this book until some years later.

There is no clear narrative in the sequencing of images in The Unseen City and few distinctive images, but as a whole the book was a highly personal enterprise. It was marked by auteurship, for although

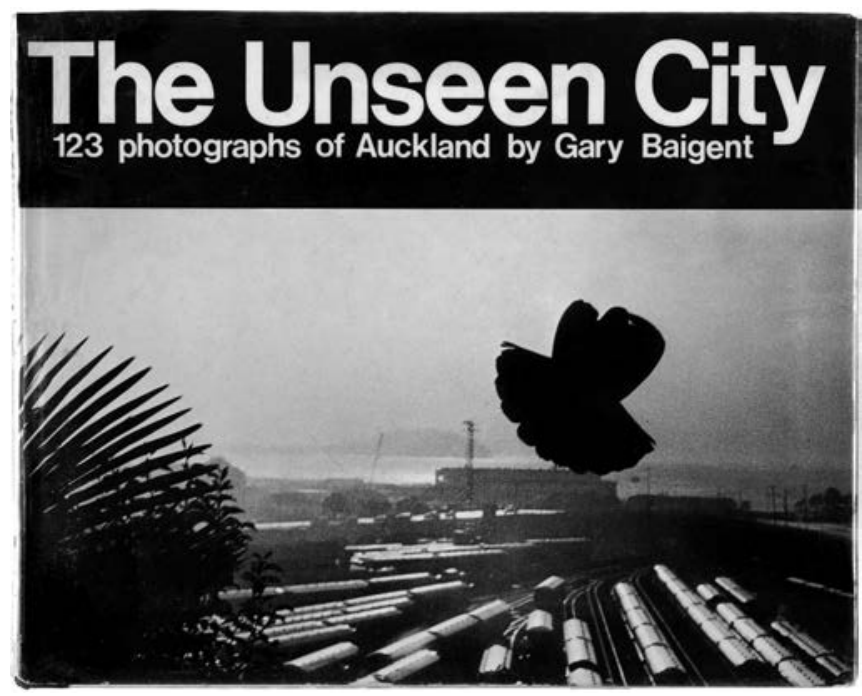

Gary Baigent, The Unseen City: 123 Photographs of Auckland, 1967, cover. Te Papa Collection. documentary, its lack of narrative pointed the reader inwards, to Baigent's vision. Here it departed from the subject focus of Westra,

Hill, Kohlap and others considered earlier. And as such it signalled the beginning of contemporary art photography in New Zealand.

The art photography movement resulted in an upsurge

in photographic publishing of photographs made with expressive intent, but surprisingly few of these could be called photobooks, for they tended to function as catalogues of work. These include group exhibition catalogues such as Three New Zealand Photographers: Gary Baigent, Richard Collins, John Fields (1973), The Active Eye: Contemporary New Zealand Photography (1975), Fragments of a World: A Collection of Photographs by New Zealand Women Photographers (1976) and Views/Exposures: 10 Contemporary New Zealand Photographers (1982); but also monographs, such as Second Nature: Peter Peryer, Photographer, New Zealand (1995) and Anne Noble: States of Grace (2001). The monographs situated the work as belonging to a world outside of the book in which they were published, rather than using it to construct a world within the book.

Nevertheless, a growing audience for contemporary photography also enabled a much smaller number of New Zealand photobooks such as Anne Noble's The Wanganui (1982), Terry O'Connor's All Good Children: Life in a New Zealand Children's Health Camp (1983) and Glenn Jowitt's Race Day (1983). More mainstream were Ans Westra's Notes on the Country I Live In (1972), Marti Friedlander's Larks in a Paradise: New Zealand Portraits (1974) and Robin Morrison's The South Island of New Zealand from the Road (1981) - each a development of the New Zealand: Gift of the Sea model into more overtly subjective territory. Combined with the popular Working Men by Glenn Busch (1984) that combined interview texts with contextual portraits, the success of these books suggests that general readers were also ready to accept that a photography book could be a personal and creative enterprise in itself.

Examination of these and more recent developments since The Unseen City are beyond the scope of this article, but I hope I have shown that there is a prehistory - however imperfectly formed - of New Zealand photobooks before the contemporary photography era in which the very concept was invented, and that photographic meaning can lie in how images are arranged together, not just in the single image that is so favoured by the museum and the collector. 


\section{REFERENCES}

Baigent, Gary. The Unseen City: One Hundred and Twenty-Three Photographs of Auckland. Auckland: Blackwood and Janet Paul, 1967.

Bigwood, Jean, Kenneth Bigwood and Monte Holcroft (text). New Zealand. Wellington: AH \& AW Reed, 1963.

Brake, Brian and Maurice Shadbolt (text). New Zealand: Gift of the Sea. Christchurch: Whitcombe \& Tombs, 1963.

Browne, VC, and Leslie Hobbs (text). The Coast. Christchurch: Whitcombe and Tombs, 1962.

Cleveland, Les. The Silent Land: A Pictorial Record of the West Coast of the South Island of New Zealand. Christchurch: Caxton Press, 1966.

Dobbie, Herbert B. New Zealand Ferns: 148 Varieties, part 1 and 2 and a combined volume. Auckland: Herbert Dobbie, 1880.

Johns, JH and CGR Chavasse (text). Westland's Wealth. Wellington: Government Printer for the New Zealand Forest Service, 1959.

Hamilton, Augustus. The Art Workmanship of the Maori Race in New Zealand. Dunedin: New Zealand Institute, 1896-1901.

Hill, Bernie and Jane Hill (text). Hey boy! Christchurch: Whitcombe \& Tombs, [1962].

Ireland, Peter. "Looking at New Zealand." Athol McCredie (ed.) Brian Brake: Lens on the World. Wellington: Te Papa Press, 2010, pp. 245-255.

Kohlap, Georg and Gay Kohlap (text). David: Boy of the High Country. Auckland: Collins, [1964].

McKay, Alexander, WJ Sollas (text). The Rocks of the Cape Colville Peninsula, Auckland, New Zealand, vols. 1 and 2. Wellington: J Mackay, Government Printer, 1905, 1906.

McDonald, Lawrence. "From the Family of Man to the Family of 'Ans': Ans Westra's Photographic Books For Children." McDonald (ed.), Handboek: Ans Westra Photographs. Wellington: Blair Wakefield Exhibitions, 2004, pp. 73-90.

Mundy, DL, with text by Ferdinand von

Hochstetter. Rotomahana and the Boiling Springs of New Zealand: A Photographic Series of Sixteen Views. London: Sampson Low, Marston, Low, and Searle, 1875
Mccraw JD. "The 'Blue Books' of H.B. Dobbie and Eric Craig." New Zealand Journal of Botany 27 (1989): 347-351. https://doi.org/10.1080/002882 5X.1989.10414116.

Mitchell, Lissa. "Promotional Landscapes: DL Mundy's 'Photographic Experiences in New Zealand." Tuhinga 20 (2009): 67-80.

Muir \& Moodie. Album of New Zealand Scenery: The Maori at Home and the Thermal Springs of the North Island. Dunedin: Muir \& Moodie, 1903.

New Zealand Government Publicity Office. New Zealand: Paradise of the Pacific. [Wellington]: New Zealand Government Publicity Office, 1928.

New Zealand Government Department of Industries and Commerce, Tourist and Publicity Publicity. New Zealand: Scenic Playground of the Pacific. [Wellington]: New Zealand Government Department of Industries and Commerce, Tourist and Publicity, 1933 and 1936.

New Zealand Railways. New Zealand Railways Illustrated. Wellington: New Zealand Railways, 1937 and 1938 editions.

Pascoe, John. The Mountains, the Bush and the Sea: A Photographic Report. Christchurch: Whitcombe \& Tombs, 1950.

Reithmaier, Gregory. Rebecca and the Maoris. Wellington: Reed, 1964

Westra, Ans. Washday at the Pa. Wellington: Government Printer for the School Publications Branch of the Department of Education, 1964.

Westra, Ans. Viliami of the Friendly Islands. Wellington: Government Printer for the Schoo Publications Branch of the Department of Education, 1964.

Westra, Ans and James E Ritchie (text). Maori. Wellington: Reed, 1967.

Whitcombe and Tombs. Pictorial New Zealand: Photographic Studies. Christchurch: Whitcombe and Tombs, [c.1944].

\section{END NOTES}

1 Sam Waagenaar, with texts by Bibeb, Heinrich Böll and Georges Simeon, Children of the World: A Photobook (London, André Deutsch, 1959). The term photobook also appears in the context of books about photographic technique. The earliest here is in the series name Fountain Photobook for camera manuals published in the 1950s. The first in the series appears to be The Leica in Professional Practice (1954).

2 David Campany, "What's in a Name?" The PhotoBook Review 7, Fall (2014): 9.

3 Gerry Badger and Martin Parr, The Photobook: A History, volume 1 (London, Phaidon, 2004), p. 6.

4 Campany, p. 9.

5 Wikipedia. "Photo-book." https:// en.wikipedia.org/wiki/Photo-book [accessed 2 October 2018].

6 Badger and Parr, p.6.

7 Patrizia Di Bello and Shamoon Zami "Introduction," Patrizia Di Bello, Collette Wilson and Shamoon Zamir (eds.), The PhotoBook, From Talbot to Ruscha and Beyond. (London: IB Taurus, 2012), p. 4.

8 The sole conceptual requirement for entry into the awards was that the book 'must focus on photographic content in a visual narrative'. "New Zealand Photobook of the Year Awards 2017", https://www. photobookof theyear.co.nz/\#criteria [accessed 26 September 2018].

9 Jörg M Colberg, "Towards a Photobook Taxonomy," Conscientious Photography Magazine, 2018, https://cphmag.com/ hotobook-taxonomy/ [accessed 3 October 2018].

10 Badger and Parr, p. 7
11 Lincoln Kirstein, "Afterword", Walker Evans and Lincoln Kirstein, American Photographs (New York: Museum of Modern Art, 1938), p. 90, quoted in Badger and Parr, p. 8.

12 Badger and Parr, p. 7.

13 The issue becomes more acute with snapshot albums, where individuals could take photographs for the purpose of compiling a narrative of thematic based album. Levin farmer Leslie Adkin is a notable case, for he produced separate albums on the courtship of his wife to be, Maud in the 1910s; the construction of the Mangahao hydro-electric scheme near his home in the early 1920s; route-finding expeditions through the Tararua Range; and family holidays, complete with hand-drawn maps. His albums are held by the Museum of New Zealand Te Papa Tongarewa and the National Library of New Zealand Puna Mātauranga o Aotearoa.

14 Three such albums are held in the Hocken Library at the University of Otago and two by the Museum of New Zealand Te Papa Tongarewa.

15 Advertisement, Star, 30 October 1884, p. 2.

16 Copies are held by the Museum of $\mathrm{New}$ Zealand Te Papa Tongarewa (AL.244 and AL.215); Hocken Library, University of Otago (P1990-015/17); and Wellington Museum.

17 JD Mccraw, "The 'Blue Books' of H.B. Dobbie and Eric Craig," p. 351.

Pictorial New Zealand, c.1944, p. 5.

19 The title first appears as FG Radcliffe and A Vaughan, Beautiful New Zealand (Auckland: Frank Duncan, 1920) and is reused for a number of publications from 1970 onwards.

20 Badger and Parr, p. 7.

21 Di Bellow and Zamir, pp. 3-4; Campany, p. 9 